\title{
New human single chain anti-idiotypic antibody against benzo[a]pyrene
}

\author{
ARTEM E. STUDENNIKOVI, VALENTIN A. USTINOVI, VERA V. MOROZOVA ${ }^{2}$, NINA V. \\ TIKUNOVA ${ }^{2}$, ANDREY N. GLUSHKOV ${ }^{1,3}$
}

${ }^{1}$ Federal State Scientific Institute, Federal Research Centre for Coal and Coal Chemistry, Siberian Branch of the Russian Academy of Sciences, Institute of Human Ecology, Kemerovo, Russia

${ }^{2}$ Federal State Scientific Institute of Chemical Biology and Fundamental Medicine, Siberian Branch of the Russian Academy of Sciences, Novosibirsk, Russia

${ }^{3}$ Federal State Educational Institute of Higher Professional Education, Kemerovo State University, Kemerovo, Russia

\begin{abstract}
The naïve library from the lymphocytes of healthy humans was screened by murine single-stranded idiotypic antibodies against benzo[a]pyrene ( $p S h)$. The phage clone which contained of anti-idiotypic antibody against benzo[a]pyrene, designated as A4, was chosen for further work because of highly specific to $\mathrm{pSh}$. The available protein databases were searched. The A4 amino acid sequence was unique and $76 \%$ identical to a sequence in antibody against interferon $\gamma$. The A4 protein was expressed in bacteria and purified by two different methods: His-tagged $A 4$ and CBD-fusion A4. Both the A4 bound to pSh and also to the human single chain idiotypic antibody against the benzo[a]pyrene (T72) by ELISA. The $K_{d}$ values of $A 4$ for $p S h$ and $T 72$ were very close: $4.44 \times 10^{-7} \mathrm{M}$ and $5.71 \times 10^{-7} \mathrm{M}$, respectively. A4 was a competitor with benzo[a]pyrene for binding sites of both idiotypic pSh and $T 72$ in competitive ELISA. Thus, A4 was a high affinity anti-idiotypic against benzo[a]pyrene which recognised pSh and T72 active sites.
\end{abstract}

Key words: anti-idiotypic antibody, benzo[a]pyrene, immunology, phage display, polycyclic aromatic hydrocarbons, single-chain antibody.

(Cent Eur J Immunol 2017; 42 (2): 123-130)

\section{Introduction}

The anti-idiotype antibodies (Ab2) contain an internal immunological image of the antigen according to the concept Jerne N.K. [1, 2]. It was suggested that Ab2 be used for immunisation rather than antigen in the case of pathogenic antigen. Eichmann K. and Rajewsky K. 1975 [3] was one of the first works in this field, in which guinea pigs were immunised by Ab2 against Streptococcus. The animals acquired of resistance against bacteria after immunisation. Nowadays it has been proposed that Ab2 be used as therapeutic antibodies [4-9]. Ab2 were used against tumour-associated antigens in mice model experiments for protective and therapeutic anti-cancer immunity [10-14]. Ab2 were suggested for the treatment of cancer in humans [15-17], including lung cancer [18-20].

The preliminary immunisation by the murine monoclonal Ab2 against benzo[a]pyrene (BP) slowed tumour growth induced by BP in animals [21]. Ab1 against BP and related $\mathrm{Ab} 2$ were found in the blood serums of healthy volunteers and patients with lung cancer [22]. However, the functions of $\mathrm{Ab} 1$ and $\mathrm{Ab} 2$ against chemical carcinogens in human cancer pathogenesis still remain poorly understood. It was assumed that $\mathrm{Ab} 1$ and $\mathrm{Ab} 2$ were able to prevent the emergence of tumours and enhance the carcinogenic effects depending on the concentrations or combination of $\mathrm{Ab} 1$ and Ab2 [23]. The recombinant Ab2 against chemical carcinogens should be used to continue the research in this field. Ab2 could be applicable as a source of an antigen in human serum Ab1 detection because Ab2 contains an internal immunological antigen image. Also, purified Ab2 could be used as a standard for the development of quantitative immunoassays for measuring Ab2 in human serum.

\section{Material and methods}

\section{Chemicals and reagents}

Suppressor E. coli strain TG1 (K12, D(lac-pro), supE, thi, hsdD5/F' traD36, proA+B+, lacIq, lacZDM15); non-suppressor E. coli strain HB2151 (K12, ara, D(lacpro), thi/F' proA+B+, lacIq, lacZDM15); E. coli strain XL10-Gold (Stratagene, La Jolla, CA, USA) (end, A1, glnV44, recA1, thi-1, gyrA96, relA1, lac, Hte, $\Delta(\mathrm{m}-$

Correspondence: Artem E. Studennikov, Federal State Scientific Institute, Federal Research Centre for Coal and Coal Chemistry,

Siberian Branch of the Russian Academy of Sciences, Institute of Human Ecology, Kemerovo, 650065, Russia, tel. +7 38425750 08, e-mail: StudennikovAE@ihe.sbras.ru

Submitted: 6.06.2016; Accepted: 1.10.2016 
crA)183, $\Delta$ (mcrCB-hsdSMR-mrr)173, tetR, F' [proAB, lacIqZ $\Delta$ M15, Tn10, (TetR Amy CmR)]); M13K07 bacteriophage; nadve combinatorial library of human $\mathrm{scFv}$ genes in M13 bacteriophage [24]; pTT10 [kindly provided to us ICBFM SB RAS Novosibirsk]. The restriction enzymes were obtained from Sibenzymes (Novosibirsk, Russia).

\section{pSh and T72 purification}

pSh was mouse idiotype scFvs against BP. T72 was human idiotype scFvs against BP. Both scFvs purifications were processed as indicated in [25] and [26], respectively. pSh and T72 have CBD in each molecule. DNA of pSh and T72 were cloned into plasmid pTT10 [25]. So, amorphous cellulose was used for both protein purifications.

\section{Synthesis of BP-BSA conjugate}

BP-BSA was synthesised by covalent coupling of hapten aldehyde group to the BSA amino groups [27].

\section{Biopanning}

The selection was performed by phage display as has been described previously [24]. Three rounds of biopanning were performed using $\mathrm{pSh}$. The microtiter plate was coated with $50 \mathrm{ml} \mathrm{pSh}(50 \mathrm{ng} / \mathrm{ml})$ or CBD $(50 \mathrm{ng} / \mathrm{ml})$, as negative control, in PBS for one hour at $37^{\circ} \mathrm{C}$. The plate was then blocked by adding $100 \mathrm{ml}$ of blocking solution PBS containing $2 \%$ BSA and $0.05 \%$ Tween 20 to each well and incubated for one hour at $37^{\circ} \mathrm{C}$ with shaking. The bacteriophage particles of sampled M13 (containing scFv genes inside and expressing scFvs as part of the surface of the phage protein $\mathrm{pIII}$ ) were added. The microtiter plate was incubated for one hour at $37^{\circ} \mathrm{C}$ with shaking. After washing, absorbed bacteriophage particles were eluted by triethylamine. When individual bacteriophage clones (48 clones) were analysed the bacteriophage particles sorption to $\mathrm{CBD}$ as negative control was extrapolated.

\section{DNA sequencing and analysis}

scFv DNA from TG1 bacterial clones was isolated by BioSilica columns (Novosibirsk, Russia). The DNA was sequenced using the primers LMB3 and pHEN-SEQ SEQ [28] and a sequencing kit BigDyeŇ Terminator v3.1 Cycling Sequencing Kit (Applied Biosystems, Foster City, $\mathrm{CA}$ ). The sequencing was performed in the inter-institutional centre of DNA analysis of the Siberian Branch of the Russian Academy of Sciences and using equipment of the Core Centre 'Genomic Technologies, Proteomics and Cell Biology' in the All-Russia Research Institute for Agricultural Microbiology.

\section{T4 purification}

The purification of His-tagged A4 was performed using $\mathrm{Ni}^{2+}$ resin as described in [26]. The resulting DNA from A4 of M13 phage encoding scFv against pSh was transformed into $E$. coli HB2151 strain for protein expression. Two hundred and fifty $\mathrm{ml}$ of LB containing ampicillin $(150 \mathrm{mg} / \mathrm{ml})$ were inoculated with $500 \mathrm{ml}$ of an overnight culture of transformed $E$. coli and cells were grown at $37^{\circ} \mathrm{C}$ with vigorous shaking until an absorbance of $0.6-1 \mathrm{OD}$ at $600 \mathrm{~nm}$ was attained. The induction of protein synthesis was induced by the addition of $1 \mathrm{mM}$ isopropyl-beta-D-thiogalactopyranoside (Helicon, Novosibirsk, Russia). Overnight after induction, the bacterial cells were harvested by centrifugation and suspended in $6 \mathrm{ml}$ of sonication buffer (PBS containing 100 mM 4-(2-aminoethyl)benzenesulfonyl fluoride (Sigma, St. Louis, MO, USA). The disrupting of the bacterial cells and the chromosomal DNA was with four 30-s cycles at 70 watts in Vibra-cell Sonic power sonicator (Sonics, Newtown, CT, USA). Insoluble cellular membranes were removed by centrifugation at $25,000 \times \mathrm{g}$ for $15 \mathrm{~min}$ at $4^{\circ} \mathrm{C}$. His-tagged $\mathrm{A} 4$ was in the supernatant and was purified by adsorption onto $\mathrm{Ni}^{2+}$ resin (Lab Instruments, Moscow, Russia) and elution with elution buffer ( $250 \mathrm{mM}$ imidazole, $\mathrm{pH}$ 6.0), followed by dialysis against a buffer solution (400 mM Tris, $\mathrm{pH}$ 8.0, $500 \mathrm{mM} \mathrm{NaCl}, 1 \mathrm{mM}$ EDTA) for 4 hours at $0^{\circ} \mathrm{C}$. The protein refolding occurred during dialysis. Quality control for protein folding was tested by binding of antibodies to antigens. Such preparation of the His-tagged A4 was $~ 90 \%$ pure as assessed by SDS-PAGE. Concentration of purified protein was determined using the BCA Protein Assay (Thermo Fisher Scientific Waltham, Massachusetts, USA) and by spectrophotometry at $280 \mathrm{~nm}$.

The A4 DNA was subcloned into the $\mathrm{NcoI}$ and BamHI sites of the pTT10 vector. In this case of CBD-fusion A4, the protein was prepared as described in [25].

\section{SDS-PAGE}

Gel electrophoresis was performed according to the method of Laemmli in $12.5 \%$ acrylamide gels. Proteins were detected in the gels by staining with $0.04 \%$ Coomassie G-250 (Bio-Rad Laboratory, Hercules, CA, USA).

\section{Direct ELISA}

Noncompetitive direct immunoassay was based on the specific binding of A4 to pSh or T72 [29]. The 96-well microtiter plates were coated with His-tagged A4 at 100 $\mathrm{ng} / \mathrm{ml}$ at $37^{\circ} \mathrm{C}$ for one hour. After each step the plates were incubated at $37^{\circ} \mathrm{C}$ on a shaker for one hour. After each incubation step the plates were washed 3 times with PBS containing $0.05 \%$ Tween 20 . After His-tagged A4 coating the plates were blocked by adding to each well $250 \mu \mathrm{l}$ of blocking solution (PBS containing 0.5\% BSA and $0.05 \%$ Tween 20). The pSh (from $0.8 \mathrm{ng} / \mathrm{ml}$ to $22 \mathrm{ng} / \mathrm{ml}$ ) or T72 (from 0.2 to $12 \mathrm{ng} / \mathrm{ml}$ ) were added. The rabbit anti-CBD $\mathrm{Ab}(1: 1000)$ and then horseradish peroxidase-labelled an- 
ti-rabbit conjugates of mouse $\mathrm{Ab}(1: 5000)$ were added to the wells successively. The binding was detected by adding of tetramethylbenzidine. The production of coloured reaction was stopped by $2 \mathrm{~N} \mathrm{HCl}$. The optical density was performed using wavelength of $450 \mathrm{~nm}$ on plate reader iMark (Bio-Rad Laboratory, Hercules, CA, USA).

In the case of CBD-fusion A4 the direct ELISA was the same except for the details. The 96-well microtiter plates were coated with CBD-fusion A4. Then after blocking pSh or T72 were added. Mouse anti-cMyc Ab (1 : 1000), which bound pSh or T72 and horseradish peroxidase-labelled anti-mouse conjugates of rabbit $\mathrm{Ab}(1: 5000)$ were used.

\section{Competitive ELISA}

The competitive ELISA was evaluated as non-competitive ELISA (described above), except of the 96-well microtiter plates were coated with $100 \mathrm{ml}$ of conjugate $\mathrm{BP}-\mathrm{BSA}$ at $2 \mathrm{ng} / \mathrm{ml}$ for overnight at $6^{\circ} \mathrm{C}$. The $\mathrm{pSh}$ or T72 (4 and $15 \mathrm{ng} / \mathrm{ml}$, respectively, corresponding to half of the maximum saturation concentration $-\mathrm{IC}_{50}$ ) were added in

Table 1. Analysis of the nucleotide sequences encoding V-, D-, and J-segments of heavy (A) and light (B) chains of A4. The comparison of the DNA sequences of A4 to germline segments

A

\begin{tabular}{|c|c|c|c|c|c|c|c|c|c|c|}
\hline \multirow[t]{2}{*}{$\#$} & \multirow[t]{2}{*}{$\begin{array}{l}\text { Germline } \\
\text { segments }\end{array}$} & \multirow[t]{2}{*}{$\begin{array}{c}\% \\
\text { identity }\end{array}$} & \multirow{2}{*}{\multicolumn{2}{|c|}{ FR/CDR }} & \multicolumn{2}{|c|}{ Mutations } & \multicolumn{4}{|c|}{$\begin{array}{l}\text { Amino acid residues } \\
\text { replacements }\end{array}$} \\
\hline & & & & & $\mathbf{R}$ & $\mathbf{S}$ & & 1 & & 2 \\
\hline \multirow[t]{4}{*}{ A4 } & \multirow[t]{2}{*}{ IGHV1-69*13 } & \multirow[t]{2}{*}{$93.75 \%$} & \multicolumn{2}{|c|}{ FR } & 10 & 0 & $\begin{array}{r}\mathrm{a} 2>\mathrm{g}, \mathrm{Q} \\
\mathrm{g} 3>\mathrm{a}, \mathrm{Q} \\
\mathrm{t} 5>\mathrm{g}, \mathrm{V} \\
\mathrm{g} 6>\mathrm{t}, \mathrm{V} \\
\mathrm{c} 7>\mathrm{g}, \mathrm{Q} \\
\mathrm{c} 16>\mathrm{g}, \mathrm{Q} \\
\mathrm{t} 49>\mathrm{g}, \mathrm{S} \\
\mathrm{g}\end{array}$ & $\begin{array}{l}>\mathrm{R}(+--) \\
>\mathrm{R}(+--) \\
>\mathrm{G}(---) \\
>\mathrm{G}(---) \\
>\mathrm{E}(++-) \\
>\mathrm{E}(++-) \\
>>\mathrm{A}(-+-) \\
>>\mathrm{a}\end{array}$ & \multicolumn{2}{|c|}{$\begin{array}{l}\mathrm{c} 117>\mathrm{g}, \mathrm{I} 39>\mathrm{M}(++-) \\
\mathrm{a} 118>\mathrm{c}, \mathrm{S} 40>\mathrm{H}(+--) \\
\mathrm{g} 119>\mathrm{a}, \mathrm{S} 40>\mathrm{H}(+--)\end{array}$} \\
\hline & & & \multicolumn{2}{|c|}{ CDR } & 6 & 1 & $\begin{array}{r}\mathrm{g} 82>\mathrm{t}, \mathrm{G} \\
\mathrm{g} 83>\mathrm{a}, \mathrm{G} \\
\mathrm{g} 104>\mathrm{c}, \mathrm{S} \\
\mathrm{a} 106>\mathrm{g}, \mathrm{S} \\
\mathrm{t} 1 \\
\mathrm{~g} 112>\mathrm{t}, \mathrm{A} \\
\mathrm{c} 113>\mathrm{a}, \mathrm{A}\end{array}$ & $\begin{array}{l}8>\mathrm{Y}(+--) \\
8>\mathrm{Y}(+--) \\
5>\mathrm{T}(+-+) \\
6>\mathrm{G}(++-) \\
1>c \\
38>\mathrm{Y}(---) \\
38>\mathrm{Y}(---)\end{array}$ & & - \\
\hline & IGHJ6*02 & $93.10 \%$ & & & & & & - & & \\
\hline & IGHD2-15 & & & & & & & - & & \\
\hline \multicolumn{11}{|l|}{$\overline{\mathbf{B}}$} \\
\hline \multirow[t]{2}{*}{$\#$} & \multirow[t]{2}{*}{$\begin{array}{l}\text { Germline } \\
\text { segments }\end{array}$} & \multirow[t]{2}{*}{$\begin{array}{c}\% \\
\text { identity }\end{array}$} & \multirow[t]{2}{*}{$\begin{array}{l}\text { FR/ } \\
\text { CDR }\end{array}$} & \multicolumn{2}{|c|}{ Mutations } & \multicolumn{5}{|c|}{$\begin{array}{l}\text { Amino acid residues } \\
\text { replacements }\end{array}$} \\
\hline & & & & $\mathbf{R}$ & $\mathbf{S}$ & & 1 & & & 3 \\
\hline \multirow[t]{2}{*}{ A4 } & \multirow[t]{2}{*}{ IGKV3-20*01 } & \multirow[t]{2}{*}{$95.04 \%$} & FR & 3 & 1 & & - & $\begin{array}{l}\text { g153>t, } \mathrm{L} \\
\mathrm{t} 158>\mathrm{c}, \mathrm{L} \\
\mathrm{a} 164>\mathrm{t}, \mathrm{Y}\end{array}$ & $\begin{array}{l}(---) \\
(---) \\
(-+-)\end{array}$ & $\mathrm{t} 312>\mathrm{c}$ \\
\hline & & & CDR & 13 & 2 & $\begin{array}{l}\mathrm{a} 80>\mathrm{g} \\
\mathrm{g} 85>\mathrm{c} \\
\mathrm{g} 110>\end{array}$ & $\begin{array}{l}27>\mathrm{R}(+--) \\
229>\mathrm{I}(+-+) \\
37>\mathrm{T}(+-+)\end{array}$ & $\begin{array}{l}\mathrm{g} 167>\mathrm{c}, \mathrm{C} \\
\mathrm{g} 169>\mathrm{a}, A\end{array}$ & $\begin{array}{l}\text { A }(-+-) \\
T(---)\end{array}$ & $\begin{array}{c}\mathrm{g} 315>\mathrm{a} \\
\mathrm{a} 320>\mathrm{t}, \mathrm{Y} 107>\mathrm{F}(-+- \\
\mathrm{g} 322>\mathrm{a}, \mathrm{G} 108>\mathrm{N}(-- \\
\mathrm{g} 323>\mathrm{a}, \mathrm{G} 108>\mathrm{N}(-- \\
\mathrm{c} 327>\mathrm{t} \\
\mathrm{c} 329>\mathrm{a}, \mathrm{S} 110>\mathrm{Y}(+-- \\
\mathrm{a} 330>\mathrm{t}, \mathrm{S} 110>\mathrm{Y}(+-- \\
\mathrm{c} 331>\mathrm{t}, \mathrm{P} 111>\mathrm{Y}(+-- \\
\mathrm{c} 332>\mathrm{a}, \mathrm{P} 111>\mathrm{Y}(+-- \\
\mathrm{t} 333>\mathrm{c}, \mathrm{P} 111>\mathrm{Y}(+-- \\
\mathrm{c} 334>\mathrm{a}\end{array}$ \\
\hline
\end{tabular}

IGKJ2*01 $89.74 \%$

$R$ and $S$ were significant and insignificant nucleotide substitutions, respectively. The $(++-)$ indicated of comparison of two amino acid residues (before and after replacement): hydrophobicity, size and physic-chemical characteristics. Percent of homology with embryonic segments was given only for $V$ and $J$ segments of the scFvs 
the presence of competitor (A4) at a concentration between 0.0016 to $0.1 \mathrm{mg} / \mathrm{ml}$. Both His-tagged A4 and CBD-fusion A4 were used. For the rabbit anti-CBD Ab $(10.8 \mathrm{ng} / \mathrm{ml})$, which bound pSh or T72 and horseradish peroxidase-labelled anti-rabbit conjugates of mouse $\mathrm{Ab}(1 \mathrm{ng} / \mathrm{ml})$ were

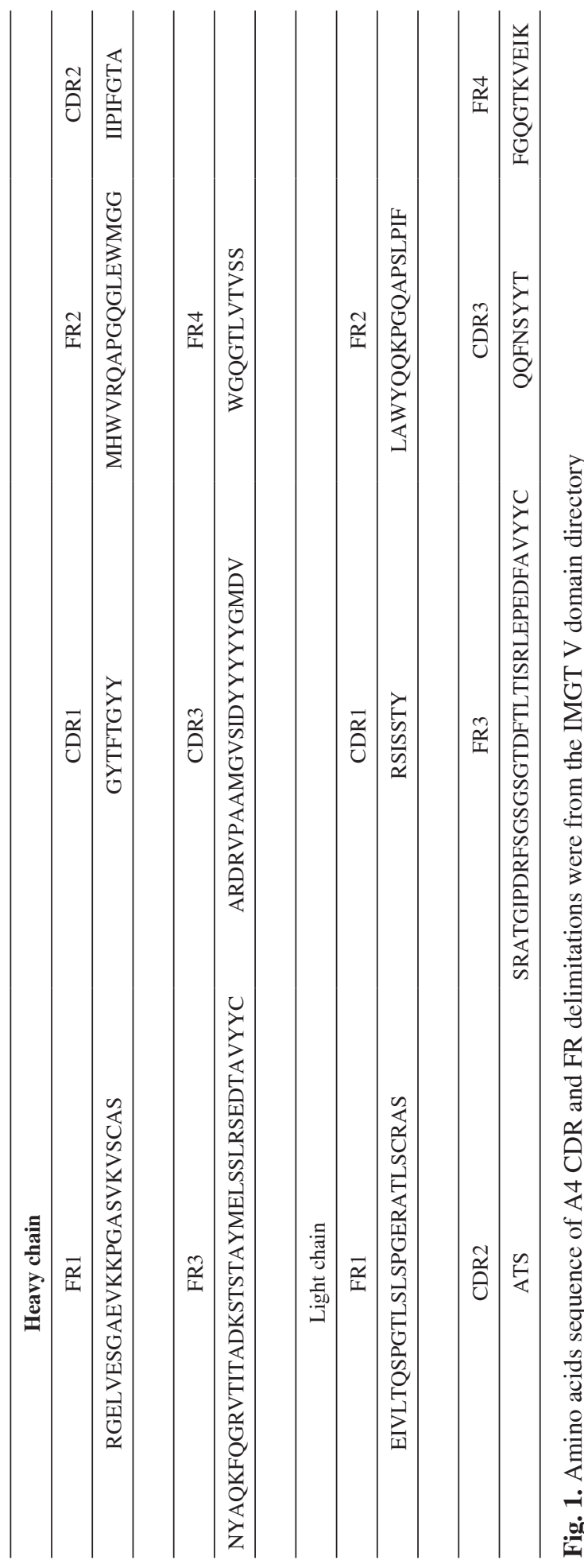

used. In case of CBD-fusion A4 the mouse anti-cMyc Ab (1 : 1000), which also bound pSh or T72 and horseradish peroxidase-labelled anti-mouse conjugates of rabbit $\mathrm{Ab}$ (1: 5000) were used.

\section{Surface plasmon resonance}

The kinetics of interaction between A4 and pSh/T72 was performed by the surface plasmon resonance instrument ProteOn XPR36 (BioRad Laboratory, Hercules, CA, USA) using purified proteins. A4 was immobilised using the amino groups on the surface of the biochip. pSh or T72 were in flow throw the chip surface as analytes at concentrations of $0.266 \mathrm{mM}, 0.532 \mathrm{mM}, 1.06 \mathrm{mM}, 2.13 \mathrm{mM}$ and $0.199 \mathrm{mM}, 0.399 \mathrm{mM}, 0.798 \mathrm{mM}, 9.97 \mathrm{mM}$, respectively. BSA was immobilised on the biochip as a negative control. The binding of pSh (T72) to BSA was taken into account at final constant calculations. Both His-tagged A4 and CBD-fusion A4 were used in surface plasmon resonance experiments and gave us the same results.

\section{Results}

\section{Selection and DNA sequence analysis of specific phages}

The selection of scFvs against pSh (mouse idiotype against BP) was carried out by phage display. The nadve combinatorial library of human scFvs was used [24], the size of which was $1.9 \times 10^{10} \mathrm{cfu} / \mathrm{ml}$, indicating that the library satisfied with high sequence diversity. The library was panned three times against immobilised pSh to microtiter plate. As a result of analysis of 48 individual bacterial clones, the 14 positive clones with the strongest response to the pSh were selected. The phagemid DNA from the 12 bacterial clones were isolated and sequenced. DNA sequencing of 12 clones showed that all contained inserts phagemid DNA encoding scFvs. Only 7 sequenced DNA samples were unique and the rest of them contained repetitions. Only one clone A4 was chosen for further analysis and work because of the preliminary experiments showed that A4 bound to pSh with high affinity (data not shown).

\section{Analysis of the amino acid and DNA sequences of A4}

The analysis of the nucleotide sequences encoding V-, D-, and J-segments of heavy and light chains of A4 was done by the IMGT V-QUEST (Table 1). V-, J-, and D-segments of A4 heavy chain belonged to IGHV1-69*13, IGHJ6*02, and IGHD2-15 family segments, respectively. Light chain of A4 applied to the family of $\kappa$-chains. V-and J-segments of A4 light chain belonged to IGKV3-20*01 and IGKJ $2 * 01$ family segments, respectively. By comparing the A4 nucleotide sequence with germline segments, it could be assumed that V-segments of the A4 were low 
Table 2. The A4 CDR3 formation by gene V-, D-, and J-segments

\begin{tabular}{cccc}
\hline V-segment & & & J-segment \\
\hline A4 HC & $\sim$ MELSSLRSEDTAVYYCAR & - & DRVPAAMGVSIDYYYYYGMDV \\
\hline A4 LC & $\sim$ LTISRLEPEDFAVYYCQQFNS & Y & YTFGGGTKLEIK \\
\hline The CDR3 is in bold. Amino acid chains start with a conservative amino acid residue - L/M89 [30]. HC - heavy chain, LC - light chain
\end{tabular}

conservative to $\mathrm{V}$ germline segments. The percentage identity ranged was $93.75 \%$ for the heavy chain and $95.04 \%$ for the light chain.

Searching the National Centre for Biotechnology Information database (NCBI, USA) using the BLAST algorithm revealed that $\mathrm{A} 4$ was unique and did not have any homology among published antibodies. The amino acid sequence was nearly identical to a sequence in antibody against INF-g (AHM25306.1) - Max score 360, Query cover $100 \%$, Ident $76 \%$ (data not shown).

Figure 1 shows the A4 amino acid sequence consisting of 236 amino acids excluding the 18 amino acid residues linker connecting the heavy and light chains. A4 is composed of 129 amino acid residues of the heavy chain and 107 amino acid residues of the light chain. The Figure 1 shows the analysis of the constant and variable amino acid sequences regions of the heavy and light chains. Interestingly, the shortest of the LCDR2 was only three amino acid residues. The HCDR3 was the longest and consisted of 23 amino acid residues.

The CDR3 region is the most variable part of the $\mathrm{scFv}$, in the formation of which Variable-, Diversity-, and Joining-segments attended. To understand and clarify the recognition of the A4 properties, the maturation mechanisms comprising $\mathrm{V} / \mathrm{D} / \mathrm{J}$ recombination and variability at junctional site of those A4 was studied and compared with their predecessor germline sequences. Table 2 presents an analysis of segment boundaries in the formation of A4. Interestingly, the HCDR3 contained no D-segment. The main part of the HCDR3 was encoded by J-segment and only two amino acids by $\mathrm{V}$-segment. In the case of A4 light chain there was one triplet for $\mathrm{Y}$ insertion between $\mathrm{V}$ - and J-segments.

\section{Expression and purification of A4}

The preliminary experiments showed that the anti-idiotype A4 bound to mouse idiotype antibody pSh with high affinity (data not shown), which is why DNA of A4 was expressed in E. coli and proteins purified in preparative amounts by affinity chromatography on a nickel resin as mentioned in the 'Materials and methods' section. Also A4 DNA was subcloned into pTT10 vector for A4 expression as a CBD-fusion. In the last case cellulose was used for A4 purification as indicated in [25]. Figure 2 shows an electrophoretogram of CBD-fusion A4 after SDS-PAGE electrophoresis. The purified A4 migrated as major bands of $\sim 51 \mathrm{kDa}$ consistent with its predicted molecular weights

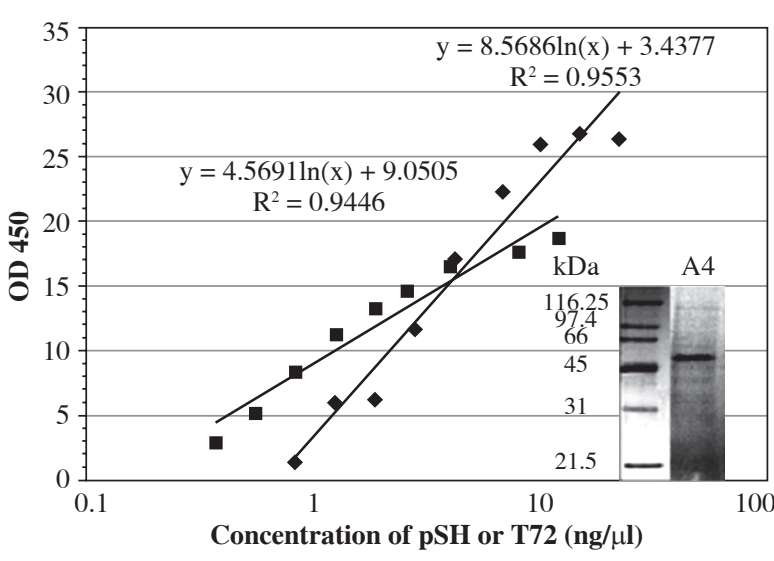

Fig. 2. The result of ELISA binding of pSh (rhombus) and $\mathrm{T} 72$ (foursquare) to microtitter plates immobilized A4. The electrophoreses was on $12.5 \%$ acrylamide gels under reducing conditions and stained with Coomassie R-250. A4 was expressed as CBD-fusion and purified on cellulose. A4 migrated as $\sim 51 \mathrm{kDa}$ protein corresponding to protein ladder

of the processed form of CBD-fusion $\mathrm{scFv}$, i.e. without a leader peptide.

\section{The Affinity of A4}

Direct ELISA was used for A4 binding estimation to murine idiotype pSh and human idiotype T72 (Fig. 2). Both His-tagged A4 and CBD-fusion A4 were used in ELISA experiments and gave us the same results (data not shown). pSh was used for phage library screening. However also A4 showed a positive reaction with the T72 in the assay used, despite the fact that the active sites of pSh and T72 were different $[25,26]$. A4 binding had a dose-dependent manner in both cases and was very similar.

The optical biosensor ProteOn (Bio-Rad, Hercules, California, USA) was used to determine the dissociation constants for purified A4 and pSh (T72) by surface plasmon resonance. A4 was immobilised onto chip GLM using amino groups. Increasing concentrations of $\mathrm{pSh}$ or T72 were in the solution: $0.266 \mathrm{mM}, 0.532 \mathrm{mM}, 1.06 \mathrm{mM}$, $2.13 \mathrm{mM}$ and $0.199 \mathrm{mM}, 0.399 \mathrm{mM}, 0.798 \mathrm{mM}, 9.97$ $\mathrm{mM}$, respectively. BSA was immobilised on the chip as 
Table 3. Equilibrium constants for binding of surface-immobilized A4 to pSh and T72

\begin{tabular}{ccccccc}
\hline & $\begin{array}{c}\mathbf{k a} \\
\left(\mathbf{M}^{-1} \mathbf{s}^{-1}\right)\end{array}$ & $\begin{array}{c}\mathbf{k d} \\
\left(\mathbf{s}^{-1}\right)\end{array}$ & $\begin{array}{c}\mathbf{K d} \\
(\mathbf{M})\end{array}$ & $\begin{array}{c}\text { Ka } \\
\left(\mathbf{M}^{-1}\right)\end{array}$ & $\begin{array}{c}\chi^{2} \\
(\mathbf{R U})\end{array}$ & Residuals \\
\hline $\mathrm{pSh}$ & $9.97 \times 10^{+2}$ & $4.43 \times 10^{-4}$ & $4.44 \times 10^{-7}$ & $2.2 \times 10^{+6}$ & 23.23 & from -20 till 20 \\
\hline $\mathrm{T} 72$ & $4.42 \times 10^{+3}$ & $2.52 \times 10^{-3}$ & $5.71 \times 10^{-7}$ & $1.7 \times 10^{+6}$ & 34.89 & from -20 till 40 \\
\hline
\end{tabular}

A

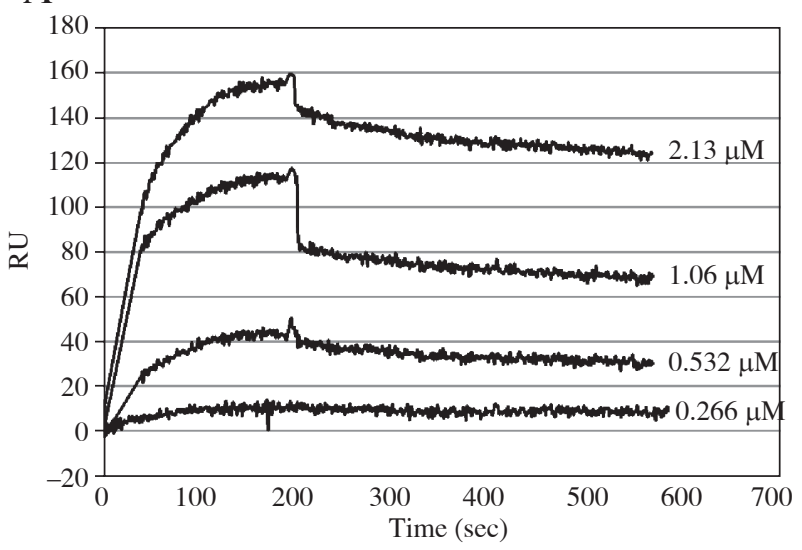

B

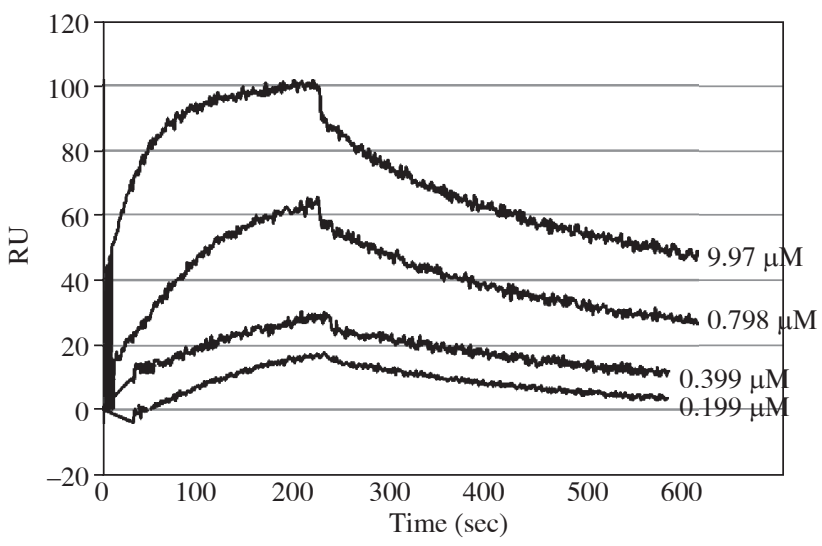

Fig. 3. Association-dissociation curves of (A) pSh and (B) T72 with chip GLM immobilized A4

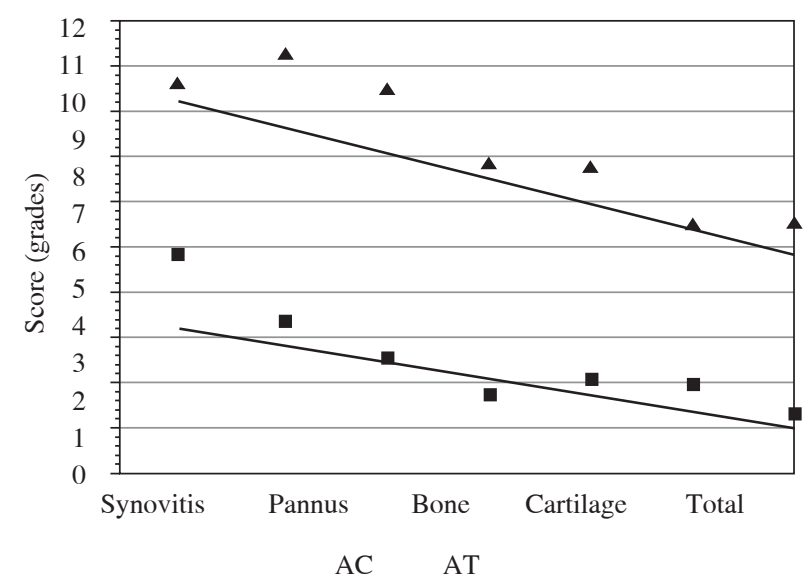

Fig. 4. The result of competitive ELISA binding of pSh (triangle) and T72 (foursquare) to immobilized BP in the presence of increasing concentration of A4

a control. Figure 3 shows the sensorgram curves A4 to pSh (A) and T72 (B). The $K_{d}$ values for His-tagged A4 and CBD-fusion A4 were the same.

The simple $1: 1$ interaction model $(\mathrm{A}+\mathrm{B}=\mathrm{AB})$ was used for the calculation of values of constants. Table 3 shows the final calculated results for the association rate constants $-\mathrm{ka}$, dissociation rate constants $-\mathrm{kd}$, dissocia- tion constants $-K_{d}$ and association constants $-K_{a}$ for A4 binding to pSh and T72. $K_{d}$ values for A4 to pSh and T72 were very close $4.44 \times 10^{-7} \mathrm{M}$ and $5.71 \times 10^{-7} \mathrm{M}$, respectively. It was correlated with ELISA result (Fig. 2) where pSh and $\mathrm{T} 72$ binding to A4 curves were almost coincided.

The competitive ELISA was assessed to define anti-idiotype A4 mimicked BP epitope and interacted with active centers of idiotype antibodies against BP (pSh and T72) (Fig. 4). An immunological plate was coated with BPBSA. The T72 and pSh (concentration at half saturation of the maximum $\mathrm{BP}$ binding $\left.-\mathrm{IC}_{50}\right)$ were in solution in the presence of increasing competitor concentrations of A4. A4 inhibited the binding of BP-BSA with both T72 and pSh in a dose dependent manner. Moreover, A4 inhibition of T72 binding to BP-BSA was stronger than in the case of pSh to BP-BSA.

\section{Discussion}

Earlier, high affinity murine scFv Ab1 against BP with $K_{d}=0.7 \times 10^{-8} \mathrm{M}[25,31]$ was obtained and monoclonal antibodies with $K_{d}=0.68 \times 10^{-10} \mathrm{M}$ [32], as well as human scFv against $\mathrm{BP}$ with $K_{d}=2.93 \times 10^{-7} \mathrm{M}$ [26]. The high affinity of human anti-idiotype scFv against BP was described for the first time in the current article.

The A4 against pSh (murine idiotypic against BP) was found after screening of the nadve combinatorial library of scFv genes from human leukocyte, which has been de- 
scribed in [25]. Nucleotide sequence analysis A4 DNA was distributed on gene families and subfamilies based on the analysis of heavy and light chains of scFv (Table 1). Interestingly, IGHV 1-69*13, which encoded the V-domain of A4 heavy chain, was found mainly in immunoglobulins expressed in B cells in chronic lymphocytic leukaemia [33]. IGHJ6*02, which encoded the J-domain of the A4 heavy chain, was heavily mutated in leukaemia [34]. IGKV3-20*01, V-domain coding A4 light chain, played an important role in the pathogenesis of eye lymphoma [35]. The percentage of homology analysed A4 V-segments with segment germ lines was very low: $93.75 \%$ and $95.04 \%$ for the heavy and light chains, respectively. The A4 light chain belonged to $\kappa$ chains $(70 \%$ of the total light chains of Ab). Also, Table 2 shows CDR3L and CDR3H formation from $\mathrm{V}$-, D-, and J-segments of DNA.

A4 was purified in two different ways: using of cellulose (Fig. 2, insert) and $\mathrm{Ni}^{2+}$-resin (data not shown). Both ways gave us the same major bands on SDS-PAGE. However, the molecular weights of the two A4 were different, because of A4 different fusions. CBD-fusion A4 migrated as band of $\sim 51 \mathrm{kDa}$ and His-tagged A4 of $\sim 31 \mathrm{kDa}$, when analysed by SDS-PAGE. CBD-fusion A4 and His-tagged A4 gave us the same results in ELISA and ProteOn experiments. Both purified A4 bound both pSh and T72 in ELISA (Fig. 2), despite the fact that pSh and T72 had different binding sites for A4. Measured $K_{d}$ values for binding A4 (His-tagged $\mathrm{A} 4$ and CBD-fusion A4) to pSh and T72 by surface plasmon resonance were very close $4.44 \times 10^{-7} \mathrm{M}$ and $5.71 \times 10^{-7} \mathrm{M}$, respectively (Table 3 ). The competitive ELISA was held in order to prove that A4 recognised the active centers of $\mathrm{pSh}$ and T72. The result is shown in Fig. 4. A4 competed with BP-BSA in binding to both pSh and T72. Thus, the A4 was an anti-idiotypic antibody and bound the active centers of pSh and T72. The amino acid sequences of pSh and T72 were presented by Ustinov et al. $[25,26]$, respectively. The identity between pSh and T72 was low, because of different amino acid sequences: Max score 185, Query cover 92\%, Ident 47\% (data not shown). However A4 carried an internal immunological image of $\mathrm{BP}$, so it could recognise of completely different idiotype antibodies.

A4 was purified and analysed for further use in the development of cancer immunodiagnostic techniques [36]. A4 could be used as an antigen to replace hazardous BP-BSA in immunoassay measure the Ab1 detection in human blood serum and also as a standard for the quantitative analysis of Ab2 against BP in human blood serum. Also, A4 could be used in creating new approaches in human cancer immunoprophylaxis. However, firstly we need to figure out immune response and inhibition pathogenic effects induced by A4 compared with those induced by BP in mouse.

This work was financially supported by the State $\mathrm{Ba}$ sic Research Program of Russia, Siberian branch Russian
Academy of Science (Goszadanie no. 0355-294-0001): Genetic bases of immune responses against chemical carcinogens and steroidal hormones in humans lung cancer and Russian Science Foundation (Grant no. 16-15-00034): Development of the test-systems for cancer risks preclinical diagnostics among workers in the coal industry.

Special thanks to Vavilov V.A. for help in computer processing, data preparation and for a fruitful discussion of the results. Also we would like to thank Grebenshchikov I.S. for assistance in ELISA.

The authors declare no conflict of interest.

\section{References}

1. Jerne NK (1974): Towards a network theory of the immune system. Ann Immunol (Paris) 125C: 373-389.

2. Jerne NK (1984): Idiotypic networks and other preconceived ideas. Immunol Rev 79: 5-24.

3. Eichmann K, Rajewsky K (1975): Induction of T and B cell immunity by anti-idiotypic antibody. Eur J Immunol 5: 661666.

4. Tornetta M, Fisher D, O’Neil K, et al. (2007): Isolation of human anti-idiotypic antibodies by phage display for clinical immune response assays. J Immunol Methods 328: 34-44.

5. Tzioufas AG, Routsias JG (2010): Idiotype, anti-idiotype network of autoantibodies: pathogenetic considerations and clinical application. Autoimmun Rev 9: 631-633.

6. van Schie KA, Wolbink GJ, Rispens T (2015): Cross-reactive and pre-existing antibodies to therapeutic antibodies - Effects on treatment and immunogenicity. MAbs 7: 662-671.

7. Tohidkia MR, Barar J, Asadi F, et al. (2012): Molecular considerations for development of phage antibody libraries. Drug J Target 20: 195-208.

8. Chin SE, Ferraro F, Groves M, et al. (2015): Isolation of high-affinity, neutralizing anti-idiotype antibodies by phage and ribosome display for application in immunogenicity and pharmacokinetic analyses. J Immunol Methods 416: 49-58.

9. Lim SY, Chan CEZ, Lisowska MM, et al. (2015): The molecular engineering of an anti-idiotypic antibody for pharmacokinetic analysis of a fully human anti-infective. PLoS One 10: e0145381

10. Yuan W, Xia G, Zhao C, et al. (2012): Anti-idiotypic single chain mimicking CA125 linked with tuftsin provides protective immunity against ovarian cancer in mice. Mol Med Rep 5: 388-394.

11. Wang JJ, Li YH, Liu YH, et al. (2010): The ability of human bispecific anti-idiotype antibody to elicit humoral and cellular immune responses in mice. Int Immunopharmacol 10: 707712 .

12. Wang JJ, Liu YH, Li GC (2015): Induction of protective and therapeutic anti-cancer immunity by using bispecific anti-idiotype antibody G22-I50 for nasopharyngeal carcinoma. Int Immunopharmacol 28: 1026-1033.

13. Luo C, Wang JJ, Li YH, et al. (2010): Immunogenicity and efficacy of a DNA vaccine encoding a human anti-idiotype single chain antibody against nasopharyngeal carcinoma. Vaccine 28: 2769-2774.

14. Chang DK, Kurella VB, Biswas S, et al. (2016): Humanized mouse G6 anti-idiotypic monoclonal antibody has therapeu- 
tic potential against IGHV1-69 germline gene-based B-CLL. MAbs 10: [Epub ahead of print].

15. Koprowski H, Herlyn D, Lubeck M, et al. (1984): Human anti-idiotype antibodies in cancer patients: Is the modulation of the immune response beneficial for the patient? Proc Natl Acad Sci U S A 81: 216-219.

16. Herlyn D, Ross AH, Koprowski H (1986): Anti-idiotypic antibodies bear the internal image of a human tumor antigen. Science 232: 100-102.

17. Reinsberg J (2007): Detection of human antibodies generated against therapeutic antibodies used in tumor therapy. Methods Mol Biol 378: 195-204.

18. Grant SC, Kris MG, Houghton AN, et al. (1999): Long survival of patients with small cell lung cancer after adjuvant treatment with the anti-idiotypic antibody BEC2 plus Bacillus Calmette-Guérin. Clin Cancer Res 5: 1319-1323.

19. Neninger E, Díaz RM, de la Torre A, et al. (2007): Active immunotherapy with $1 \mathrm{E} 10$ anti-idiotype vaccine in patients with small cell lung cancer: report of a phase I trial. Cancer Biol Ther 6: 145-150.

20. Hernández AM, Vázquez AM (2015): Racotumomab-alum vaccine for the treatment of non-small-cell lung cancer. Expert Rev Vaccines 14: 9-20.

21. Chagnaud JL, Faibre S, Geffard M (1994): Curative effects on rat sarcomas obtained after a treatment combining two monoclonal antibodies. Anti-Cancer Drugs 5: 361-366.

22. Ustinov VA, Matveeva VA, Kostyanko MA, et al. (2013): Antibodies against benzo[a]pyrene in immunized mouse and in lung cancer patients. Exp Oncol 35: 207-210.

23. Glushkov AN (2014): Immunological disbalance in carcinogenesis. Medical Hypotheses 83: 166-171.

24. Batanova TA, Ulitin AB, Zhirakovskaya EV, et al. (2006): Construction and characterization of combinatorial naive phage library of human scFvs. Mol Genetics Microbiol Virol 3: 35-41.

25. Ustinov VA, Averjanov AV, Glushkov AN (2014): Purification and characterization of mouse single-chain antibody against polycyclic aromatic hydrocarbons. Journal of Immunoassay and Immunochemistry 35: 428-441.

26. Ustinov VA, Studennikov AE, Vavilov VA, et al. (2015): Generation and Characterization of Human Single-Chain Antibodies Against Polycyclic Aromatic Hydrocarbons. Immunological Investigations 44: 536-552.

27. Kostyanko MV, Glushkov AN (1998): Synthesis of hapten-protein conjugate. Patent RF 2141114.

28. Vikhrova MA, Shveygert MV, Khrapov EA, et al. (2010): Selection of naturally occurring autoantibodies to interleukin-18 from phage display library. Hum Antibodies 19: 71-78.

29. Glushkov AN, Kostyanko MV, Cherno SV, et al. (1998): Immunoassay of antibodies to benz[a]pyren. Experim Oncol 20: 74-76.

30. Lefranc MP, Pommie C, Ruiz M, et al. (2003): IMGT unique numbering for immunoglobulin and $\mathrm{T}$ cell receptor variable domains and Ig superfamily V-like domains. Dev Comparative Immunol 27: 55-77.

31. Karsunke XYZ, Wang H, Weber E, et al. (2012): Development of single-chain variable fragment $(\mathrm{scFv})$ antibodies against hapten benzo[a]pyrene: a binding study. Anal Bioanal Chem 402: 499-507.

32. Karsunke XYZ, Pschenitza M, Rieger M, et al. (2011): Screening and characterization of new monoclonal anti-benzo[a]pyrene antibodies using automated flow-through microarray technology. Journal of Immunological Methods 371: 81-90.

33. Que X, Widhopf GF, Amir S, et al. (2013): IGHV1-69-encoded antibodies expressed in chronic lymphocytic leukemia react with malondialdehyde-acetaldehyde adduct, an immunodominant oxidation-specific epitope. PLoS One 8: e65203.

34. Muggen AF, Pillai SY, Kil LP, et al. (2015): Basal Ca(2+) signaling is particularly increased in mutated chronic lymphocytic leukemia. Leukemia 29: 321-328.

35. Zhu D, Lossos C, Chapman-Fredricks JR, et al. (2013): Biased immunoglobulin light chain use in the Chlamydophila psittaci negative ocular adnexal marginal zone lymphomas. Am J Hematol 88: 379-384.

36. Glushkov A (2013): Clinical immunology carcinogenesis: new challenges and prospects. Rus J Immunology 7: 27-34. 